\title{
Seroprevalence of rubella among pregnant women in Khartoum state, Sudan
}

\author{
O. Adam, ${ }^{1}$ T. Makkawi, ${ }^{1}$ A. Kannan ${ }^{2}$ and M.E. Osman ${ }^{7}$
}

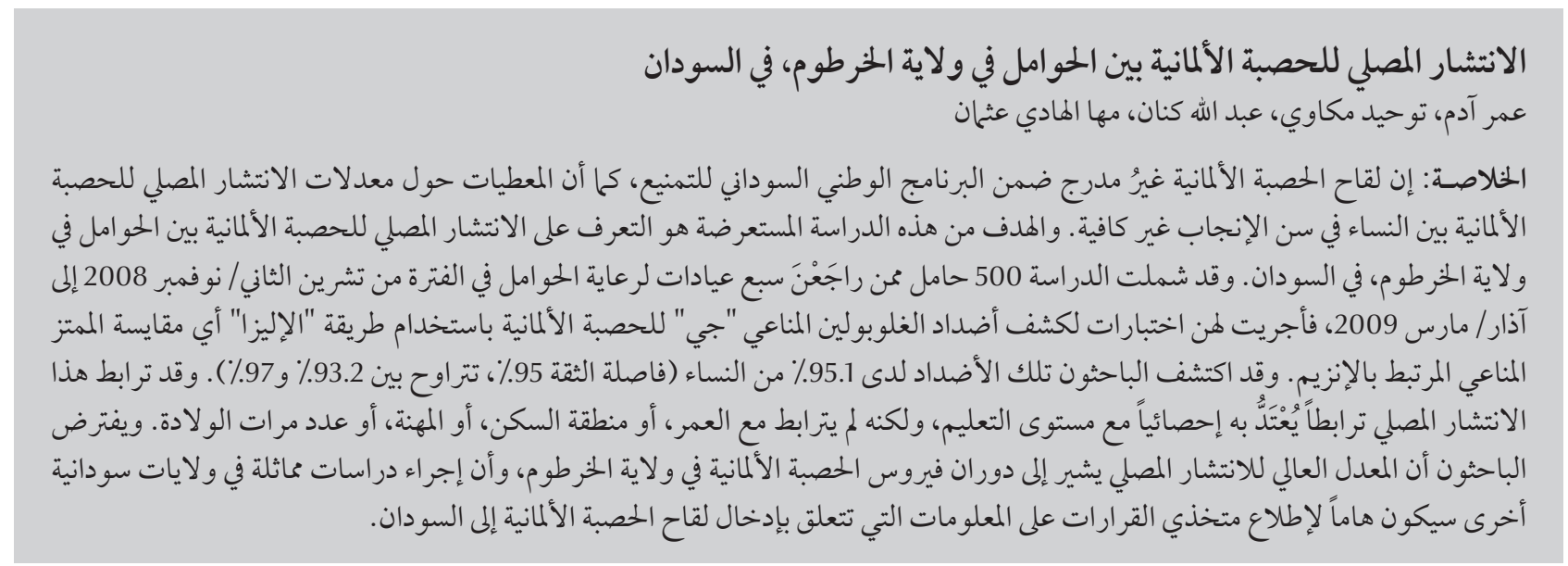

ABSTRACT Rubella vaccine is not included in the Sudanese national immunization programme, and data on the prevalence of rubella among women of childbearing age are inadequate. The objective of this cross-sectional study was to determine the seroprevalence of rubella among pregnant women in Khartoum state, Sudan. A total of 500 pregnant women who visited 7 antenatal clinics from November 2008 to March 2009 were examined for the presence of rubella IgG antibodies using ELISA. Rubella IgG antibodies were detected in 95.1\% (95\% Cl: 93.2\%-97.0\%) of women. This seroprevalence was significantly associated with education level, but not with age, residence area, occupation or parity. We presume this high seroprevalence indicates a high circulation of wild rubella virus in Khartoum state. Similar studies in other Sudanese states would be important for informing a decision to introduce rubella vaccine to Sudan.

\section{Séroprévalence de la rubéole chez les femmes enceintes dans l'État de Khartoum (Soudan)}

RÉSUMÉ Le vaccin contre la rubéole ne fait pas partie du programme national de vaccination du Soudan, et les données sur la prévalence de la rubéole chez les femmes en âge de procréer sont insuffisantes. L'objectif de la présente étude transversale était de déterminer la séroprévalence de la rubéole chez les femmes enceintes dans l'État de Khartoum (Soudan). Au total, 500 femmes enceintes ayant consulté dans sept établissements de soins prénatals entre novembre 2008 et mars 2009 ont été examinées pour le dépistage des anticorps antirubéoleux de type IgG à l'aide de la méthode ELISA. Des anticorps antirubéoleux de type IgG ont été détectés chez 95,1\% des femmes (IC à 95 \% : 93,2 \%-97,0 \%). La séroprévalence était significativement associée au niveau d'études, mais pas à l'âge, ni à la zone de résidence, ni au métier, ni à la parité. Nous avons supposé que cette forte prévalence reflétait une forte circulation du virus sauvage de la rubéole dans l'État de Khartoum. Des études similaires dans d'autres états du Soudan seraient essentielles pour appuyer la décision d'introduction du vaccin contre la rubéole dans le pays.

${ }^{\prime}$ Department of Medical Biotechnology, Commission for Biotechnology and Genetic Engineering, National Centre for Research, Khartoum, Sudan (Correspondence to O. Adam: omerhadi@yahoo.com).

${ }^{2}$ Department of Obstetrics and Gynaecology, Faculty of Medicine, Alzaiem Alazhari University, Khartoum, Sudan.

Received: 24/05/12; accepted: 19/06/12 


\section{Introduction}

Rubella is an infectious viral disease caused by the rubella virus. The disease commonly occurs in childhood and is characterized by a mild, maculopapular rash. However, if rubella occurs during the early months of pregnancy, the virus may infect the fetus and result in miscarriage, stillbirth or an infant with congenital rubella syndrome (CRS). The most common clinical manifestations ofCRS include cardiac, ophthalmic, auditory and neurological defects [1]. Rubella is a vaccine-preventable disease where the primary purpose of vaccination against rubella is to prevent the occurrence of CRS [2]. Due to effective vaccination programmes, rubella and CRS have become rare diseases in many industrialized countries [1]. However, CRS remains a major cause of developmental anomalies in many developing countries where rubella vaccine has not yet introduced [3]. It is estimated that more than 100000 infants are born with CRS each year, mostly in developing countries [4]. Hence, the World Health Organization (WHO) recommended all countries not using rubella vaccine to assess their rubella situation and to make plans for the introduction of the vaccine. In this regard, it is helpful to assess the susceptibility profile of women of childbearing age by conducting antenatal serosurveys in such countries [2].

Rubella vaccine is not included in the Sudanese national immunization programme, and data on the prevalence of rubella among women of childbearing age are inadequate [5]. Furthermore, there is no routine surveillance for CRS, and data on its incidence are extremely scarce [6]. Sudanese surveillance for measles and rubella since 2006 has reported that rubella infection is a frequent cause of none-measles rash [7]. In the light of this situation, we conducted this study to determine the seroprevalence of rubella among pregnant women attending antenatal clinics in Khartoum state, Sudan.

\section{Methods}

\section{Study setting and subjects}

The study was conducted in Khartoum state, the national capital of Sudan, which covers an area of $28000 \mathrm{~km}^{2}$. The state is comprised of 3 main regions: Khartoum, Bahry and Omdurman, and is administratively divided into 7 localities with an estimated population of 5 million in 2008.

This cross-sectional study was conducted between November 2008 and March 2009 at 7 antenatal clinics in those 7 different localities of the state. A total of 500 healthy pregnant women, at any gestational age and permanently resident in Khartoum state were enrolled. This sample size was determined based on $95 \%$ confidence interval (CI), $5 \%$ level of precision, a design effect of 2 and a previous seroprevalence of $79.5 \%$ [5].

\section{Ethical approval}

The study protocol was reviewed and approved by the Health Research Ethics Committee of the Federal Ministry of Health, Sudan. All subjects were informed about the study and consented before enrolment.

\section{Data collection}

Following aseptic techniques, $3 \mathrm{~mL}$ of venous blood were obtained from each subject and sera were extracted and stored at $-20^{\circ} \mathrm{C}$ until tested. In addition, a questionnaire including information on demographic characteristics and history of rubella vaccination was administered for each subject. To screen for rubella $\operatorname{Ig} G$ antibodies in sera samples, a commercial enzyme-linked immunosorbent assay kit (rubella virus IgG ELISA, DRG GmbH) was used. Based on the manufacturer's instructions sera samples with a titre $<10$ $\mathrm{IU} / \mathrm{mL}$ were classified as negative for rubella IgG; samples with titres of $\geq 15$ $\mathrm{IU} / \mathrm{mL}$ were classified as positive; and samples with a titre of 10 to $<15 \mathrm{IU} / \mathrm{mL}$ were classified as equivocal.

\section{Data analysis}

The statistical analysis was performed using SPSS software, version 12. Categorical data were analysed by the chisquared test or Fisher exact method as appropriate. A $P$-value of $<0.05$ was considered statistically significant.

\section{Results}

The main characteristics of the pregnant women are presented in Table 1 . The mean age of the participants was 26.4 years, ranging between $16-47$ years, and half of them $(50.5 \%)$ were $\leq 25$ years. Most of the studied women (43.1\%) were resident in Omdurman. Of the women, $14.1 \%$ were illiterate and $67.7 \%$ had completed primary or secondary school education. The majority of the women were housewives (91.0\%). The analysis of obstetric profile revealed that $74.8 \%$ of the pregnant women were multigravida, and the mean number of pregnancies was 3.4 , ranging between 1-14 pregnancies. Two-thirds of the women $(325,66.5 \%)$ were enrolled at their third trimester of pregnancy while only $45(11.0 \%)$ were at their first trimester. History of miscarriage was reported by $146(29.9 \%)$ of the investigated women. It was clearly stated that none of the tested women had been vaccinated against rubella before.

Of the 500 pregnant women, 465 were positive for rubella $\operatorname{IgG}, 24$ were negative and 11 were equivocal. Those with equivocal results were excluded from the study, leaving a total of 489 women for further analysis. Accordingly, the seroprevalence of rubella in Khartoum state was found to be $95.1 \%$ (95\% CI: 93.2\%-97.0\%), while the susceptibility to rubella among the examined women was $4.9 \%$ (95\% CI: $3.0 \%-6.8 \%)$.

The statistical analysis of categorical data did not show significant association between the seroprevalence of rubella and each of age (Pearson $\chi^{2}=0.003, \mathrm{df}$ $=1, P=0.959)$, residence area (Pearson 


\begin{tabular}{|c|c|c|c|c|c|c|}
\hline \multicolumn{7}{|c|}{$\begin{array}{l}\text { Table } 1 \text { Seroprevalence of rubella among pregnant women attending } 7 \text { antenata } \\
\text { clinics in Khartoum state, Sudan }(n=489)\end{array}$} \\
\hline \multirow[t]{3}{*}{ Variable } & \multirow{2}{*}{\multicolumn{2}{|c|}{ Total }} & \multicolumn{4}{|c|}{ Rubella seroprevalence } \\
\hline & & & \multicolumn{2}{|c|}{ Positive } & \multicolumn{2}{|c|}{ Negative } \\
\hline & No. & $\%$ & No. & $\%$ & No. & $\%$ \\
\hline \multicolumn{7}{|l|}{ Age (years) } \\
\hline$\leq 25$ & 247 & 50.5 & 235 & 95.1 & 12 & 4.9 \\
\hline \multirow[t]{2}{*}{$>25$} & 242 & 49.5 & 230 & 95.0 & 12 & 5.0 \\
\hline & \multicolumn{6}{|c|}{$\chi^{2}=0.003, \mathrm{df}=1, P=0.959$} \\
\hline \multicolumn{7}{|l|}{ Residence area } \\
\hline Khartoum & 106 & 21.7 & 98 & 92.5 & 8 & 7.5 \\
\hline Bahry & 172 & 35.2 & 161 & 93.6 & 11 & 6.4 \\
\hline \multirow[t]{2}{*}{ Omdurman } & 211 & 43.1 & 206 & 97.6 & 5 & 2.4 \\
\hline & \multicolumn{6}{|c|}{$\chi^{2}=5.31, \mathrm{df}=2, P=0.070$} \\
\hline \multicolumn{7}{|l|}{ Education } \\
\hline Illiterate & 69 & 14.1 & 60 & 87.0 & 9 & 13.0 \\
\hline Primary & 186 & 38.0 & 183 & 98.4 & 3 & 1.6 \\
\hline Secondary & 145 & 29.7 & 138 & 95.2 & 7 & 4.8 \\
\hline \multirow[t]{2}{*}{ University } & 89 & 18.2 & 84 & 94.4 & 5 & 5.6 \\
\hline & \multicolumn{6}{|c|}{$\chi^{2}=14.2, \mathrm{df}=3, P=0.003$} \\
\hline \multicolumn{7}{|l|}{ Occupation } \\
\hline Not working & 445 & 91.0 & 422 & 94.8 & 23 & 5.2 \\
\hline \multirow[t]{2}{*}{ Working } & 44 & 9.0 & 43 & 97.7 & 1 & 2.3 \\
\hline & \multicolumn{6}{|c|}{$\chi^{2}=0.719, \mathrm{df}=1, P=0.396$} \\
\hline \multicolumn{7}{|l|}{ Parity } \\
\hline Primigravida & 123 & 25.2 & 113 & 91.9 & 10 & 8.1 \\
\hline \multirow[t]{2}{*}{ Multigravida } & 366 & 74.8 & 352 & 96.2 & 14 & 3.8 \\
\hline & \multicolumn{6}{|c|}{$\chi^{2}=3.66, \mathrm{df}=1, P=0.056$} \\
\hline Total & 489 & 100.0 & 465 & 95.1 & 24 & 4.9 \\
\hline
\end{tabular}

$\left.\chi^{2}=5.31, \mathrm{df}=2, P=0.070\right)$, occupation (Pearson $\chi^{2}=0.719, \mathrm{df}=1, P=0.396$ ) and parity (Pearson $\chi^{2}=3.66, \mathrm{df}=1, P$ $=0.056)$. However, the education level was significantly associated with rubella seroprevalence $\left(\right.$ Pearson $\chi^{2}=14.2, \mathrm{df}=$ $3, P=0.003)$

\section{Discussion}

Our findings demonstrated a high rubella seroprevalence of 95.1\% (95\% CI: 93.2\%-97.0\%) among pregnant women in Khartoum state. We presume this indicates a heavy circulation of wild rubella virus in Sudan, since rubella vaccination is not yet practised in the country. This presumption is supported by the recent reports of the Sudanese previously reported in many developing countries that were not using rubella vaccine [8], including countries from the World Health Organization Eastern Mediterranean Region, such as the Islamic Republic of Iran, where the seroprevalence of rubella was $91.1 \%$ among pregnant women [9]. In addition, a similar high rubella prevalence of $95.3 \%$ has been reported in some African countries, such as South Africa and Mozambique $[10,11]$, besides, a slightly higher prevalence of $97.9 \%$ among Nigerian pregnant women [12].

Several factors may influence the seroprevalence of rubella among and within countries $[13,14]$. Nevertheless, this study showed an insignificant association between rubella seroprevalence and age, residence area, occupation and parity. Such a result is expected in countries with a high rubella prevalence $[10,12]$. However, the seroprevalence of rubella was significantly associated with education level $(P=0.003)$. The seroprevalence was higher among educated women (94.4\%98.4\%) compared with illiterate women in whom the seroprevalence was $87.0 \%$ (95\% CI: 79.1\%-94.9\%). This could be attributed to the increased probability of acquiring rubella infection during the early school years [1].

On the other hand, the current study demonstrated a low rubella susceptibility rate of $4.9 \%$ (95\% CI: 3.0\%-6.8\%) among the investigated subjects. This result does not exclude the risk of CRS in our population, as CRS can occur even when susceptibility levels are below $10 \%$ [13]. In accordance with this fact, we have recently documented the occurrence of CRS in Sudan, when 11 CRS case were laboratory confirmed in a hospital-based study during June 2005 to May 2006 [6]. Consequently, it is highly recommended to assess the burden of CRS in Sudan because a high number of CRS cases might occur if this low susceptibility is due to recent rubella outbreaks. The burden of CRS can be assessed through conducting active CRS surveillance and testing for 
rubella IgM in suspected infants aged $\leq 6$ months, either nationwide or in selected urban and rural populations [13]. Another method for assessing the CRS burden would be a retrospective review of hospital records [15].

In conclusion, this brief report is one of the most recent studies documenting the situation of rubella in Sudan. It showed a high seroprevalence of rubella among pregnant women in Khartoum state. We recommend conducting more studies on rubella seroprevalence in women of childbearing age in other Sudanese regions, which will provide an indirect measure of the burden of CRS and will help the Sudanese health authorities in considering the inclusion of rubella vaccine in Sudan.

\section{Acknowledgements}

We would like to thank Dr Ahmed K.M. Ali, from the Commission for Biotechnology and Genetic
Engineering, Sudan, for offering his time during the preparation of this manuscript. We are also grateful to the women who participated in this study and to the doctors, nurses and technicians at the antenatal clinics for their cooperation and help during the collection of samples.

Funding: This study received a financial support from the Sudan Academy of Sciences, Sudan.

Competing interests: None declared.

\section{References}

1. Best J. Rubella. Seminars in Fetal and Neonatal Medicine, 2007, 12:182-192.

2. World Health Organization. Rubella vaccines: WHO position paper. Weekly Epidemiological Record, 2000, 75:161-169.

3. Banatvala JE, Brown DW. Rubella. Lancet, 2004, 363:1127-1137.

4. Cutts FT, Vynnycky E. Modelling the incidence of congenital rubella syndrome in developing countries. International Journal of Epidemiology, 1999, 28:1176-1184.

5. Elbushi AM. Sero-epidemiology of rubella in Sudanese pregnant women in Khartoum state [PhD thesis]. Khartoum, Sudan, University of Khartoum, 1997.

6. Adam $\mathrm{O}$ et al. Primary investigation of 31 infants with suspected congenital rubella syndrome in Sudan. Clinical Microbiology and Infection, 2010, 16:678-682.

7. Measles bulletin. December 2009. World Health Organization Regional Office for the Eastern Mediterranean [online]. (http://www.emro.who.int/vpi/measles/media/pdf/MeaslesBulletin_December09.pdf, 11 June 2013).

8. Cutts FT et al. Control of rubella and congenital rubella syndrome (CRS) in developing countries, part 1: burden of disease from CRS. Bulletin of the World Health Organization, 1997, 75:55-68.
9. Majlessi F et al. Rubella serology in pregnant women attending health centres of Tehran University of Medical Sciences. Eastern Mediterranean Health Journal, 2008, 14:590-594.

10. Corcoran C, Hardie D. Seroprevalence of rubella antibodies among antenatal patients in the Western Cape. South African Medical Journal, 2005, 95:688-690.

11. Barreto J et al. Antenatal rubella serosurvey in Maputo, Mozambique. Tropical Medicine and International Health, 2006, 11:559-564.

12. Mohammed-Durosinlorun A et al. Prevalence of rubella $\lg G$ antibodies among pregnant women in Zaria, Nigeria. International Health, 2010, 2:156-159.

13. Guidelines for surveillance of congenital rubella syndrome and rubella. Field test version 1999. Geneva, World Health Organization, 1999 (WHO/V\&B/99.2).

14. Palihawadana $\mathrm{P}$ et al. Seroprevalence of rubella antibodies among pregnant females in Sri Lanka. Southeast Asian Journal of Tropical Medicine and Public Health, 2003, 34:398-404.

15. Bloom S et al. Congenital rubella syndrome in Morocco: a rapid retrospective assessment. Lancet, 2005, 365:135-141. 